\title{
Development and Evaluation of a TaqMan Real-Time PCR Assay for Fusarium oxysporum f. sp. spinaciae
}

P. A. Okubara, United States Department of Agriculture-Agricultural Research Service (USDA-ARS), Root Disease and Biological Control Research Unit, Pullman, WA 99164; L. A. Harrison, former graduate student, and E. W. Gatch, graduate student, Washington State University Mount Vernon NWREC, Mount Vernon 98273; G. Vandemark, USDA-ARS, Grain Legume Genetics and Physiology Research Unit, Pullman, WA 99164; K. L. Schroeder, Department of Plant Pathology, Washington State University, Pullman 99164; and L. J. du Toit, Washington State University Mount Vernon NWREC

\begin{abstract}
Okubara, P. A., Harrison, L. A., Gatch, E. W., Vandemark, G., Schroeder, K. L., and du Toit, L. J. 2013. Development and evaluation of a TaqMan real-time PCR assay for Fusarium oxysporum f. sp. spinaciae. Plant Dis. 97:927-937.

Fusarium oxysporum f. sp. spinaciae, causal agent of spinach Fusarium wilt, is an important soilborne pathogen in many areas of the world where spinach is grown. The pathogen is persistent in acid soils of maritime western Oregon and Washington, the only region of the United States suitable for commercial spinach seed production. A TaqMan real-time polymerase chain reaction (PCR) assay was developed for rapid identification and quantification of the pathogen, based on sequencing the intergenic spacer (IGS) region of rDNA of isolates of the pathogen. A guanine single-nucleotide polymorphism (G SNP) was detected in the IGS sequences of 36 geographically diverse isolates of F. oxysporum f. sp. spinaciae but not in the sequences of 64 isolates representing other formae speciales and 33 isolates representing other fungal species or genera. The SNP was used to develop a probe for a real-time PCR assay. The real-time PCR assay detected $F$. oxysporum $\mathrm{f}$. sp. spinaciae at 3-14,056 CFU/g of soil in 82 soil samples collected over 3 years from naturally infested spinach seed production sites in western Washington, although a reliable detection limit of the assay was determined to be $11 \mathrm{CFU} / \mathrm{g}$ of soil. A significant $(P<0.05)$,

positive correlation between enumeration of $F$. oxysporum on Komada's agar and quantification of the pathogen using the TaqMan assay was observed in a comparison of 82 soil samples. Correlations between pathogen DNA levels, Fusarium wilt severity ratings, and spinach biomass were significantly positive for one set of naturally infested soils but not between pathogen DNA levels, wilt incidence ratings, and spinach biomass for other soil samples, suggesting that soilborne pathogen population is not the sole determinant of spinach Fusarium wilt incidence or severity. The presence of the G SNP detected in one isolate of each of $F$. oxysporum ff. spp. lageneriae, lilii, melongenae, and raphani and reaction of the real-time PCR assay with 16 of 22 nonpathogenic isolates of $F$. oxysporum associated with spinach plants or soil in which spinach had been grown potentially limits the application of this assay. Nonetheless, because all isolates of F. oxysporum f. sp. spinaciae tested positive with the real-time PCR assay, the assay may provide a valuable means of screening for resistance to Fusarium wilt by quantifying development of the pathogen in spinach plants inoculated with the pathogen.
\end{abstract}

The long day length, mild temperatures, and dry summer weather in the maritime Pacific Northwest (PNW) region of the United States render this the only region of the United States suitable for spinach (Spinacia oleracea L.) seed production $(22,49)$. Spinach seed crops in western Washington and Oregon produce up to $50 \%$ of the United States and $25 \%$ of the world spinach seed supply annually (22). However, the acidic soils characteristic of this region are highly conducive to Fusarium wilt of spinach $(18,22)$. The disease is caused by Fusarium oxysporum f. sp. spinaciae W.C. Snyder \& H.N. Hansen, a soilborne pathogen that survives saprophytically in crop residues, as asymptomatic infections in plant roots, and as persistent chlamydospores $(4,6,8,54)$.

Fusarium wilt of spinach has become the primary limiting factor for spinach seed production in the PNW (22) and, therefore, in the United States. Planting resistant cultivars is the most environmentally and economically feasible option for management of this

Corresponding author: L. J. du Toit, E-mail: dutoit@wsu.edu

References to a company and/or product by the United States Department of Agriculture are only for the purposes of information and do not imply approval or recommendation of the product to the exclusion of others that may also be suitable.

* The $\boldsymbol{e}$-Xtra logo stands for "electronic extra" and indicates that a supplementary figure and two supplementary tables are available online.

Accepted for publication 21 January 2013.

http://dx.doi.org/10.1094/PDIS-03-12-0317-RE

(C) 2013 The American Phytopathological Society disease $(17,18,22)$. However, availability of resistant cultivars is limited (21) and, most importantly, seed crops are grown on contract; therefore, spinach seed growers have little choice in the parent lines they plant (22). Expenses for management of this disease by soil fumigation are cost prohibitive for spinach seed crops, and rotations of 10 to 15 years are currently required to avoid significant yield losses from the disease. Alternative management strategies and a reliable means of predicting the disease risk associated with specific field sites are necessary for improving spinach seed yields and productivity in the PNW.

The F. oxysporum complex consists of nonpathogenic and pathogenic strains of $>120$ formae speciales (29). Strains of nonpathogenic Fusarium spp., including nonpathogenic $F$. oxysporum as well as formae speciales of $F$. oxysporum, are ubiquitous in soils (27). In general, subspecific strains are morphologically indistinguishable, and reliable identification of a forma specialis requires pathogenicity tests $(8,23)$. Identification of formae speciales of $F$. oxysporum by pathogenicity tests and enumeration by plating on agar media are time consuming, require extensive mycological expertise, and are not suitable for large-scale pathogen sampling (44). There is no known teleomorph for F. oxysporum (44) and, in such clonally reproducing organisms, lineage-specific mutations are passed to subsequent generations in the absence of recombination (42) and changes in host range. Molecular approaches have helped address limitations in identifying and enumerating isolates of some formae speciales and even races within formae speciales (23). A DNA array for three major root rot and wilt pathogens of tomato enabled simultaneous detection of picogram amounts of DNA of the three pathogens from agricultural samples (45). Polymerase chain reaction (PCR)-based assays for several Fusarium wilt pathogens, including Fusarium oxysporum ff. spp. ciceris (40), canariensis (Canary Island date 
palm) (53), and cubense (46), targeted random amplified polymorphic DNA (RAPD) or unique and, therefore, specific genomic DNA sequences of unknown function. A restriction fragment length polymorphism PCR assay based on the intergenic spacer (IGS) region of ribosomal DNA (rDNA) of isolates of $F$. oxysporum $\mathrm{f}$. sp. vasinfectum was also reported (62). Forma specialis-specific molecular assays based on single-copy amplified regions $(58,60)$ have been deployed successfully for $F$. oxysporum f. sp. ciceris
$(34,35)$. A monophyletic lineage has been hypothesized for $F$. oxysporum f. sp. spinaciae based on amplified fragment length polymorphisms and mitochondrial DNA sequence analyses $(7,27)$.

The objective of this study was to determine whether sequence diversity in the IGS rDNA of PNW isolates of $F$. oxysporum $\mathrm{f}$. sp. spinaciae was adequately conserved to develop a quantitative realtime PCR assay for this pathogen but variable enough to distinguish isolates of the pathogen from isolates of other formae spe-

Table 1. Fusarium oxysporum isolates used to develop a TaqMan real-time polymerase chain reaction (PCR) assay for the spinach Fusarium wilt pathogen, F. oxysporum f. sp. spinaciae

\begin{tabular}{|c|c|c|c|c|c|c|c|c|c|}
\hline \multirow[b]{2}{*}{ F. oxysporum f. sp. } & \multirow[b]{2}{*}{ Isolate } & \multirow[b]{2}{*}{ Geographic origin } & \multirow[b]{2}{*}{ Host $^{\mathrm{b}}$} & \multicolumn{2}{|c|}{ Pathogenicity tests on ${ }^{a}$} & \multirow[b]{2}{*}{ SNP $^{c}$} & \multirow[b]{2}{*}{$\mathbf{C}_{t}{ }^{d}$} & \multirow[b]{2}{*}{ GenBank $^{\mathrm{e}}$} & \multirow[b]{2}{*}{ Source $^{\mathrm{f}}$} \\
\hline & & & & Original & Spinach & & & & \\
\hline spinaciae & Fus001 & Skagit Co., WA & Spinach & + & + & G & 22.17 & FJ972801 & This study \\
\hline spinaciae & Fus003 & Skagit Co., WA & Spinach & + & + & G & 22.44 & HQ233090 & This study \\
\hline spinaciae & Fus004 & Skagit Co., WA & Spinach & + & + & G & 21.45 & HQ233091 & This study \\
\hline spinaciae & Fus057 & Skagit Co., WA & Spinach & + & + & G & 14.64 & FJ972802 & This study \\
\hline spinaciae & Fus058 & Skagit Co., WA & Spinach & + & + & G & 14.64 & FJ972803 & This study \\
\hline spinaciae & Fus059 & Skagit Co., WA & Spinach & + & + & G & n.a. & FJ972804 & This study \\
\hline spinaciae & Fus061 & Skagit Co., WA & Spinach & + & + & G & 14.77 & FJ972805 & This study \\
\hline spinaciae & Fus193 & Skagit Co., WA & Spinach & + & + & G & n.a & HQ233092 & This study \\
\hline spinaciae & Fus194 & Skagit Co., WA & Spinach & + & + & G & n.a & HQ233140 & This study \\
\hline spinaciae & Fus200 & Skagit Co., WA & Spinach & + & + & G & n.a & HQ233093 & This study \\
\hline spinaciae & Fus253 & Skagit Co., WA & Spinach & + & + & G & n.a & HQ233094 & This study \\
\hline spinaciae & Fus258 & Skagit Co., WA & Spinach & + & + & G & n.a & HQ233095 & This study \\
\hline spinaciae & Fus261 & Skagit Co., WA & Spinach & + & + & G & n.a & HQ233096 & This study \\
\hline spinaciae & $103 \mathrm{C} \# 1$ & Skagit Co., WA & Spinach & + & + & G & 19.81 & HQ233097 & This study \\
\hline spinaciae & 202D\#1 & Skagit Co., WA & Spinach & + & + & $\mathrm{G}$ & 20.91 & HQ233098 & This study \\
\hline spinaciae & 203C\#1 & Skagit Co., WA & Spinach & + & + & G & 19.93 & HQ233099 & This study \\
\hline spinaciae & 304D\#1 & Skagit Co., WA & Spinach & + & + & G & 20.79 & HQ233100 & This study \\
\hline spinaciae & 404ABmaleA & Skagit Co., WA & Spinach & + & + & G & 20.21 & HQ233101 & This study \\
\hline spinaciae & $\mathrm{AC} 2$ & Washington & Spinach & + & + & G & 12.09 & HQ233104 & 21 \\
\hline spinaciae & ATCC18780 & Arkansas & Spinach & + & + & G & 12.26 & HQ233105 & 21 \\
\hline spinaciae & ATCC34299 & California & Spinach & + & + & G & 12.35 & HQ233106 & 21 \\
\hline spinaciae & $\mathrm{FO} 23$ & Washington & Spinach & + & + & G & 12.52 & HQ233107 & 21 \\
\hline spinaciae & MF5 & Arkansas & Spinach & + & + & G & 13.00 & HQ233108 & 21 \\
\hline spinaciae & MF9 & Arkansas & Spinach & + & + & G & 12.43 & HQ233109 & 21 \\
\hline spinaciae & MF15 & Arkansas & Spinach & + & + & G & 13.79 & HQ233110 & 21 \\
\hline spinaciae & MF34 & Arkansas & Spinach & + & + & G & 13.69 & HQ233111 & 21 \\
\hline spinaciae & MF42 & Arkansas & Spinach & + & + & G & 12.63 & HQ233112 & 21 \\
\hline spinaciae & MF68 & Tennessee & Spinach & + & + & $\mathrm{G}$ & 12.08 & HQ233113 & 21 \\
\hline spinaciae & MF69 & Tennessee & Spinach & + & + & $\mathrm{G}$ & 11.54 & HQ233114 & 21 \\
\hline spinaciae & OK11 & Oklahoma & Spinach & + & + & G & 11.57 & HQ233115 & 21 \\
\hline spinaciae & SP2 & Japan & Spinach & + & + & G & 11.01 & HQ233116 & 21 \\
\hline spinaciae & SP3 & Japan & Spinach & + & + & G & 12.32 & HQ233117 & 21 \\
\hline spinaciae & SP6 & Japan & Spinach & + & + & G & 12.04 & HQ233118 & 21 \\
\hline spinaciae & FRC O-1136 & California & NR & Unk & Unk & G & 19.50 & HQ233139 & S. N. Smith \\
\hline spinaciae & $\mathrm{Ky}-2$ & Japan & NR & + & + & G & 23.91 & $\mathrm{AB} 211861$ & 39 \\
\hline spinaciae & NRRL26871 & Japan & Spinach & Unk & Unk & G & 21.34 & DQ831888 & 48 \\
\hline apii & Foa 47 & California & Celery & + & Unk & A & - & HQ233131 & T. Gordon \\
\hline apii & FRC O-1120 & California & Celery & Unk & Unk & $\mathbf{G}$ & 22.48 & HQ233133 & S. N. Smith \\
\hline apii & ORA-3 & California & Celery & + & Unk & A & - & HQ233132 & T. Gordon \\
\hline apii & SUF1017 & Japan & NR & Unk & - & $\mathbf{G}$ & 22.47 & $\mathrm{AB} 106048$ & 39 \\
\hline asparagi & FOA50 & Australia & Asparagus & Unk & Unk & A & - & DQ831886 & 48 \\
\hline batatas & NRRL22535 & Germany & Sweet potato & Unk & Unk & $\mathrm{A}$ & - & DQ831895 & 48 \\
\hline betae & Fo17 & Minnesota & Sugar beet & + & Unk & n.a. & - & $\ldots$ & L. Hanson \\
\hline betae & Fob9 & Texas & Sugar beet & + & Unk & n.a. & - & $\ldots$ & L. Hanson \\
\hline callistephi & NRRL22536 & Germany & Onion & Unk & Unk & A & - & DQ831897 & 48 \\
\hline ciceris & RAB-Rz0 & Córdoba, Spain & Chickpea & + & Unk & n.a. & - & $\ldots$ & B. Landa \\
\hline ciceris & RAB-Rz5 & Córdoba, Spain & Chickpea & + & Unk & n.a. & - & $\ldots$ & B. Landa \\
\hline
\end{tabular}

${ }^{\text {a }}$ Original $=$ original host $+=$ pathogenic on the host of origin or on spinach; Unk $=$ unknown; $-=$ nonpathogenic on the host of origin or on spinach; \pm for isolate F. oxysporum f. sp. melonis 9016 designates differential responses of host cultivars carrying resistance (-) or susceptibility $(+)$ to race 2.

${ }^{\mathrm{b}}$ Plant host of origin. Latin names inferred from cited formae speciales or common names of the host plants: asparagus = Asparagus officinalis, barrel medic $=$ Medicago truncatula, , celery = Apium graveolens var. dulce, chickpea $=$ Cicer arietinum, cotton $=$ Gossypium hirsutum, cucumber $=$ Cucumis sativus, daffodil $=$ Narcissus pseudonarcissus, fava bean $=$ Vicia faba , heliotrope $=$ Heliotropium sp., iris $=$ Iris sp., kidney bean $=$ Phaseolus vulgaris, lettuce $=$ Lactuca sativa, onion $=$ Allium cepa, pea $=$ Pisum sativum, prickly pear $=$ Opuntia $\mathrm{sp} .$, radish $=$ Raphanus sativus, spinach $=$ Spinacia oleracea, staghorn sumac $=$ Rhus typhina, stock $=$ Matthiola sp., sugar beet $=$ Beta vulgaris subsp. vulgaris, sweet potato $=$ Ipomoea batatas, tomato $=$ Lycopersicon esculentum, trumpet lily $=$ Lilium longiflorum, , and tulip $=$ Tulipa $\mathrm{sp} . \mathrm{NR}=$ not reported.

${ }^{\mathrm{c}}$ Single-nucleotide polymorphism (SNP) at position 615 in the ribosomal DNA intergenic spacer sequence of $F$. oxysporum $\mathrm{f}$. sp. spinaciae reference strain Fus001. $\mathrm{G}=$ guanine, $\mathrm{A}=$ adenine, n.a. = not assayed. Bold indicates the $\mathrm{G}$ SNP in a nontarget isolate.

${ }^{\mathrm{d}}$ Average cycle threshold $\left(\mathrm{C}_{\mathrm{t}}\right)$ values from duplicate TaqMan real-time PCR assays for $F$. oxysporum $\mathrm{f}$. sp. spinaciae; $-=$ no DNA amplification detected in the TaqMan real-time PCR assays; n.a. = not assayed. Bold indicates amplification of a nontarget isolate

${ }^{\mathrm{e}}$ GenBank accession number.

${ }^{\mathrm{f}}$ Source of isolate or reference. 
ciales. The IGS region of nuclear rDNA was targeted because of availability of sequence data $(39,48)$ and because this region is more variable for isolates of $F$. oxysporum than the internal transcribed spacer (ITS) rDNA region (48) (P. Okubara and L. du Toit, unpublished data). This study documents the development of a TaqMan real-time PCR assay for $F$. oxysporum f. sp. spinaciae based on a guanine $(\mathrm{G})$ single-nucleotide polymorphism (SNP) identified in the IGS rDNA region, demonstrates use of the real- time PCR assay to avoid labor-intensive pathogenicity tests, and illustrates potential application as well as limitations of the assay for enumerating populations of the spinach Fusarium wilt pathogen in naturally infested soils.

\section{Materials and Methods}

Fungal isolates. The initial 110 isolates of Fusarium used in this study are listed in Table 1 . Isolates of $F$. oxysporum f. sp. spi-

Table 1. (continued from preceding page)

\begin{tabular}{|c|c|c|c|c|c|c|c|c|c|}
\hline \multirow[b]{2}{*}{ F. oxysporum f. sp. } & \multirow[b]{2}{*}{ Isolate } & \multirow[b]{2}{*}{ Geographic origin } & \multirow[b]{2}{*}{ Host $^{\mathbf{b}}$} & \multicolumn{2}{|c|}{ Pathogenicity tests on ${ }^{a}$} & \multirow[b]{2}{*}{$\mathbf{S N P}^{\mathrm{c}}$} & \multirow[b]{2}{*}{$\mathrm{C}_{t}{ }^{\mathrm{d}}$} & \multirow[b]{2}{*}{ GenBank $^{\text {e }}$} & \multirow[b]{2}{*}{ Source $^{f}$} \\
\hline & & & & Original & Spinach & & & & \\
\hline cepae & Foc1 & Brighton, $\mathrm{CO}$ & Onion bulb & + & Unk & n.a. & - & $\ldots$ & H. Schwartz \\
\hline cepae & Foc8 & West Slope, CO & Onion bulb & + & Unk & n.a. & - & 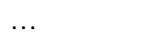 & H. Schwartz \\
\hline cepae & Fus064 & La Salle, CO & Onion bulb & + & Unk & A & - & FJ972810 & H. Schwartz \\
\hline cepae & NRRL22538 & Germany & Onion & Unk & Unk & A & - & DQ831891 & 48 \\
\hline сиситегіпит & GL265 & Florida & Cucumber & + & Unk & A & - & HQ233134 & T. Gordon \\
\hline сиситеrinum & FRC O-1086 & Japan & Cucumber & Unk & Unk & A & n.a. & HQ233135 & J. P. Jones \\
\hline сиситеrinum & Rif-1 & Maryland & NR & Unk & - & G & 20.20 & AB 106052 & 39 \\
\hline fabae & NRRL26411 & Washington & Fava bean & Unk & Unk & $\mathrm{A}$ & - & DQ831902 & 48 \\
\hline gladioli & Fus071 & Washington & Iris & Unk & Unk & A & n.a. & FJ972811 & G. Chastagner \\
\hline gladioli & WBCTI-5 & Washington & Iris & Unk & Unk & n.a. & - & $\ldots$ & G. Chastagner \\
\hline gladioli & Fus073 & Washington & Iris & Unk & Unk & A & n.a. & FJ972812 & G. Chastagner \\
\hline gladioli & Fus074 & Maryland & Iris & Unk & Unk & A & - & FJ981676 & G. Chastagner \\
\hline heliotropa & NRRL26412 & Japan & Heliotrope & Unk & Unk & A & - & DQ831903 & 48 \\
\hline lactucae & F9501 & Japan & Lettuce & + & Unk & A & - & DQ831893 & 48 \\
\hline lilii & $85 / 209 \mathrm{k}$ & United States & NR & Unk & Unk & A & - & & M. Kawabe \\
\hline lilii & FRC O-0326 & United States & Trumpet lily & Unk & Unk & G & 23.92 & HQ233136 & R. Linderman \\
\hline lycopersici & $325-3$ & Japan & Tomato & Unk & Unk & n.a. & - & $\ldots$ & D. Fravel \\
\hline matthiolae & $880116 a$ & Germany & NR & Unk & - & G & 21.18 & AB106054 & 39 \\
\hline matthiolae & NRRL22545 & SE Asia & Stock & Unk & Unk & A & - & DQ831899 & 48 \\
\hline medicaginis & NRRL22546 & Texas & Barrel medic & Unk & Unk & A & - & DQ831901 & 48 \\
\hline melonis & TX388 & Washington & Cucumber & Unk & Unk & A & - & DQ831887 & 48 \\
\hline melonis & 8701 & Washington & Melon & Unk & Unk & n.a. & - & $\ldots$ & B. Landa \\
\hline melonis & 9016 race 2 & Washington & Melon & \pm & Unk & n.a. & 21.76 & $\ldots$ & P. Chang/B. Landa \\
\hline narcissi & Fus103 & Washington & Daffodil & Unk & Unk & A & n.a. & FJ981677 & G. Chastagner \\
\hline narcissi & Fus107 & Netherlands & Daffodil & + & Unk & A & - & FJ981678 & G. Chastagner \\
\hline narcissi & Fus110 & South Carolina & Daffodil & + & Unk & A & - & FJ981679 & G. Chastagner \\
\hline narcissi & Fus113 & Colorado & Daffodil & + & Unk & A & n.a. & FJ981680 & G. Chastagner \\
\hline opuntiarum & NRRL28934 & Colorado & Prickly pear & Unk & Unk & A & - & DQ831884 & 48 \\
\hline phaseoli & NRRL26445 & Washington & Kidney bean & Unk & Unk & A & - & DQ831900 & 48 \\
\hline phaseoli & B13 & Washington & Kidney bean & + & Unk & A & - & $\ldots$ & L. Hanson \\
\hline phaseoli & B291 & Washington & Kidney bean & + & Unk & A & - & $\ldots$ & L. Hanson \\
\hline pisi & Fop1 & California & Pea & + & Unk & n.a. & - & $\ldots$ & D. Inglis \\
\hline pisi & Fop5(G) & Grant Co., WA & Pea & + & Unk & n.a. & - & $\ldots$ & D. Inglis \\
\hline pisi & Fop22 & Oregon & Pea & + & Unk & n.a. & - & $\ldots$ & W. Boge \\
\hline pisi & Fop35 & Columbia Basin & Pea & + & Unk & n.a. & - & $\ldots$ & W. Boge \\
\hline pisi & Fop241 & Columbia Basin & Pea & + & Unk & n.a. & - & $\ldots$ & W. Boge \\
\hline pisi & Fus066 & Columbia Basin & Pea & + & Unk & A & n.a. & FJ972808 & D. Inglis \\
\hline pisi & Fus068 & Columbia Basin & Pea & + & Unk & A & n.a. & FJ972809 & D. Inglis \\
\hline raphani & FRC O-1115 & Israel & NR & Unk & Unk & A & - & HQ233125 & S. N. Smith \\
\hline raphani & FRC O-1135 & Oregon & NR & Unk & Unk & A & - & HQ233126 & S. N. Smith \\
\hline raphani & FRC O-2007 & Oregon & NR & Unk & Unk & A & - & HQ233127 & C. Kistler \\
\hline raphani & FRC O-2008 & Oregon & NR & Unk & Unk & $\mathrm{A}$ & - & HQ233128 & C. Kistler \\
\hline raphani & FRC O-2036 & Oregon & NR & Unk & Unk & $\mathrm{A}$ & - & HQ233129 & C. Kistler \\
\hline raphani & FRC O-2062 & $\ldots$ & Radish & Unk & Unk & A & - & HQ233130 & K. O’Donnell \\
\hline raphani & Fus054 & $\ldots$ & Radish & + & - & A & - & FJ972806 & 19 \\
\hline raphani & Fus055 & $\ldots$ & Radish & + & - & A & - & FJ972807 & 19 \\
\hline raphani & VSP08-21A & $\ldots$ & Radish & + & - & A & n.a. & HQ233119 & 19 \\
\hline raphani & VSP08-21B & $\ldots$ & Radish & + & - & A & n.a. & HQ233120 & 19 \\
\hline raphani & VSP08-21C & $\ldots$ & Radish & + & - & A & n.a. & HQ233121 & 19 \\
\hline raphani & VSP08-21D & $\ldots$ & Radish & + & - & A & n.a. & HQ233122 & 19 \\
\hline rhois & NRRL26227 & $\ldots$ & Staghorn sumac & Unk & Unk & A & - & DQ831898 & 48 \\
\hline lycopersici & $\ldots$ & $\ldots$ & NR & Unk & n.a. & A & - & $\ldots$ & B. Landa \\
\hline tulipae & GGGADT-1 & $\ldots$ & Tulip & Unk & Unk & n.a. & - & $\ldots$ & G. Chastagner \\
\hline tulipae & Fus078 & $\ldots$ & Tulip & Unk & Unk & A & n.a. & FJ981681 & G. Chastagner \\
\hline tulipae & Fus085 & $\ldots$ & Tulip & Unk & Unk & A & n.a. & FJ981682 & G. Chastagner \\
\hline tulipae & GGHGT-5 & $\ldots$ & Tulip & Unk & Unk & n.a. & - & & G. Chastagner \\
\hline tulipae & Fus097 & Washington & Tulip & Unk & Unk & $\mathrm{A}$ & n.a. & FJ981683 & G. Chastagner \\
\hline vasinfectum & FOV14 & California & Cotton & Unk & Unk & A & - & DQ831885 & 48 \\
\hline F. oxysporum & Fo-Fsp7 & Algeria & NR & Unk & Unk & n.a. & - & $\ldots$ & 35 \\
\hline F. oxysporum & Fo-Fsp9 & Algeria & NR & Unk & Unk & n.a. & - & $\ldots$ & 35 \\
\hline F. oxysporum & VSP08-41-1 & Skagit Co., WA & Spinach & - & - & $\mathbf{G}$ & 19.31 & HQ233123 & This study \\
\hline F. oxysporum & VSP08-41-5 & Skagit Co., WA & Spinach & - & - & A & n.a. & HQ233124 & This study \\
\hline F. oxysporum & $502 \mathrm{~A} \# 2$ & Skagit Co., WA & Spinach & - & - & A & - & HQ233137 & 14 \\
\hline
\end{tabular}


naciae from L. J. du Toit's culture collection at the Washington State University (WSU) Mount Vernon Northwestern Washington Research \& Extension Center (NWREC) were obtained from spinach seed crops in western Washington that exhibited typical symptoms of Fusarium wilt (11). The isolates, designated "Fus," were tested for pathogenicity on spinach as described below. Additional isolates were obtained from plant debris washed through a series of sieves (4-, 2-, and $0.5-\mathrm{mm}^{2}$ aperture). Debris retained on the $0.5-\mathrm{mm}^{2}$ sieve was dried in a laminar flow hood, and 10 to 12 pieces were transferred to a plate of Komada's agar medium (43). Fusarium isolates were also collected from soil samples using dilution plating (44). In summary, soil samples were sieved to eliminate plant debris, and $10 \mathrm{~g}$ of dry soil was added to $90 \mathrm{ml}$ of autoclaved $0.1 \%$ water agar. Each soil suspension was placed on a shaker for $12 \mathrm{~min}$ at $250 \mathrm{rpm}$, and three aliquots were transferred serially to $0.1 \%$ water agar to achieve $10^{-1}, 10^{-2}$, and $10^{-3}$ dilutions. A 1-ml aliquot of each dilution was spread onto Komada's agar medium on duplicate plates, and the plates were monitored for 7 to 14 days. Candidate $F$. oxysporum colonies were streaked onto potato dextrose agar (PDA) (Difco Laboratories) for single-spore isolation or hyphal-tip transfer. Additional isolates were obtained from J. C. Correll (University of Arkansas), and DNA extracts of other isolates were provided by cooperators (Table 1).

Fungal isolates were cultured at room temperature in natural daylight for up to 4 weeks on PDA or for 10 to 30 days on carnation leaf agar (CLA) (50). F. oxysporum isolates were identified on the basis of morphological characteristics on PDA and CLA, as described by Leslie and Summerell (44). Each isolate represented a single genotype after single-spore isolation or hyphal-tip transfer. For long-term storage, mycelium of each isolate was grown over sterilized, 1.5-cm-diameter disks of Filter Paper 413 (VWR Scientific) on PDA. Colonized disks were placed in sterilized coin envelopes, dried in a laminar flow hood for $24 \mathrm{~h}$, and stored with anhydrous calcium sulfate (DrieRite; Mallinckrodt Baker, Inc.) at $-20^{\circ} \mathrm{C}$.

To propagate inoculum, three 5-mm-diameter agar plugs of the appropriate isolate were placed in $500 \mathrm{ml}$ of pasteurized, Ritzville coarse silty loam soil from Lind, WA that was supplemented with $1 \%$ (wt/wt) ground oatmeal, moistened with sterilized water $(15 \%$ $\mathrm{wt} / \mathrm{wt}$ ), and incubated at room temperature for 4 weeks in the dark. Fungal populations were quantified by suspending $100 \mathrm{mg}$ of infested soil-oatmeal in $5 \mathrm{ml}$ of sterile water, from which 10-fold serial dilutions were spread in triplicate onto plates of $2 \%$ water agar $(0.2 \mathrm{ml} /$ plate/dilution $)$, and incubated at room temperature in the dark for 2 days. Inoculum density was calculated as the average number of CFU/g of soil.

Pathogenicity tests. The root-dip inoculation method of Haglund (28), with minor modifications, was used to evaluate PNW isolates of $F$. oxysporum for pathogenicity on spinach. For each isolate, a 1- $\mathrm{mm}^{2}$ agar plug was transferred from the margin of a 5day culture on PDA to $50 \mathrm{ml}$ of Kerr's broth (41) in Erlenmeyer flasks. The flasks were placed on a shaker at $125 \mathrm{rpm}$ for 5 to 7 days at room temperature. The Kerr's broth was then filtered through four layers of cheesecloth to separate mycelia from spores, and the spore suspension diluted to approximately $5 \times 10^{5}$ spores/ml for root dip inoculations.

A proprietary spinach inbred line, 9420.553 (Alf Christianson Seed Co.), was used for pathogenicity testing because of tolerance of this line to thrips feeding injury, a persistent problem in the greenhouse. Seedlings were grown for 30 days at $20^{\circ} \mathrm{C}$ under a 9-h photoperiod in RediEarth seedling starter mix (SunGro Horticulture) in 72-cell flats (TLC Polyform, Inc.). The root plugs of 4 to 5 seedlings (= replications) were injured manually to provide wounding for infection, then swirled in $100 \mathrm{ml}$ of the appropriate spore suspension for $60 \mathrm{~s}$. Inoculated seedlings were transplanted individually into $12-\mathrm{cm}$-diameter plastic pots containing Sunshine Professional Growing Mix No. 1 (SunGro Horticulture). Pots were arranged in a randomized complete block design (RCBD) and maintained in a greenhouse at $28 \pm 3^{\circ} \mathrm{C}$ for 4 to 6 weeks to promote Fusarium wilt. The pathogenicity tests were repeated. For each test, four or five replicate noninoculated plants served as a negative control treatment, for which seedlings were treated similarly to the inoculated plants but dipped in sterilized water; and four or five replicate plants were inoculated with a known pathogenic isolate, Fus001, as a positive control treatment.

Disease severity was recorded weekly for each plant on a 0 to 100 scale based on the percentage of leaf pairs (ranging from four to eight true-leaf pairs per plant) showing Fusarium wilt. Taproots, crowns, and secondary roots were washed, cut lengthwise, surface sterilized in $0.6 \% \mathrm{NaOCl}$ for $4 \mathrm{~min}$, rinsed three times in sterilized water, and placed on PDA for 5 days to monitor growth of $F$. oxysporum. Fungal isolates were examined for species identification.

The pathogenicity to spinach was tested similarly for 12 isolates of $F$. oxysporum f. sp. spinaciae obtained from Arkansas, California, Oklahoma, Tennessee, and Washington, as well as 3 isolates from Japan provided by Fiely et al. (21); an isolate of each of $F$. oxysporum ff. spp. apii, cucumerinum, matthiolae, and spinaciae from Kawabe et al. (39); and $6 \mathrm{PNW}$ isolates of $F$. oxysporum f. sp. raphani (Table 1). The pathogenicity of the remaining fungal isolates listed in Table 1 and obtained from hosts of origin other than spinach was assumed to have been determined by the source laboratories.

DNA extraction from mycelia and soils. Fusarium isolates were cultured on half-strength PDA for 4 to 8 days at room temperature under natural light. Two agar plugs (each 4 to $6 \mathrm{~mm}$ in diameter) of each isolate were transferred to $30 \mathrm{ml}$ of half-strength potato dextrose broth (PDB) in a 125-ml flask. The flasks were placed on a shaker at $125 \mathrm{rpm}$ for 5 days. Mycelium was collected on a moistened Whatman number 4 filter disk in a sterilized Buchner funnel and macerated in Cell Lysis Solution CLS-Y (FastDNA kit; MP Biomedicals) using the FastPrep FP120 homogenizer (Qbiogene, ) at a speed of $6 \mathrm{~m} / \mathrm{s}$ for $40 \mathrm{~s}$. DNA was extracted using the FastDNA kit as outlined by the manufacturer for fungi. DNA was quantified using Hoechst 33258 dye (Bio-Rad) and a Tecan Safire fluorometer (Tecan).

Soil samples $(0.8 \mathrm{~g})$ naturally infested or inoculated with $F$. oxysporum f. sp. spinaciae were extracted using pressure cycling technology (Pressure BioSciences, Inc.) and the UltraClean Soil DNA Kit (MO BIO Laboratories), as described by Okubara et al. (51). Briefly, each soil sample was combined with $60 \mu \mathrm{l}$ of S1, $200 \mu \mathrm{l}$ of inhibitor removal solution, $300 \mu \mathrm{l}$ of bead solution, and $100 \mathrm{mg}$ of washed Amberlite-XAD-4 (Sigma-Aldrich), and subjected to 20 cycles of $135 \mathrm{mPa}(20,000 \mathrm{psi})$ for $20 \mathrm{~s}$ alternated with ambient pressure for $10 \mathrm{~s}$, using the Barocycler NEP 3229 (Pressure BioSciences, Inc.). Clarified supernatants were processed with S2, S3, and S4 buffers (52). Extractions for each soil sample were done in triplicate.

IGS amplification, sequence determination, and alignments. Primers CNL12 and CNS1 (Table 2) were used to generate genomic fragments of the IGS region of PNW isolates of $F$. oxysporum from spinach (Fus001, -057, -058, -059, and -061), iris (Fus071, -073, and -074), daffodil (Fus103, -107, -110, and -113), tulip (Fus078, -085, and -097), pea (Fus065, -066, -068, and -070), radish (Fus054 and -055), and onion (Fus064). Each PCR reaction was performed in a $20-\mu$ l reaction containing $1 \times$ PCR buffer $(20$ $\mathrm{mM}$ Tris- $\mathrm{HCl}[\mathrm{pH} 8.4]$ and $50 \mathrm{mM} \mathrm{KCl}), 3.75 \mathrm{mM} \mathrm{MgCl}_{2} 300 \mu \mathrm{M}$ each dNTP, $1.2 \mu \mathrm{M}$ each forward and reverse primer, 3 units of Taq polymerase (Invitrogen Corp.), and $50 \mathrm{ng}$ of genomic DNA. Amplification was performed in a PTC 200 thermocycler (MJ Research) using the following thermocycling profile: $94^{\circ} \mathrm{C}$ for 3 min; 35 cycles of $94^{\circ} \mathrm{C}$ for $1 \mathrm{~min}, 60^{\circ} \mathrm{C}$ for $1.5 \mathrm{~min}$, and $72^{\circ} \mathrm{C}$ for $2.5 \mathrm{~min}$; and a final extension at $72^{\circ} \mathrm{C}$ for $10 \mathrm{~min}$. Primers were removed from the PCR product prior to sequencing using ExoSAPIT (USB) or by passage through Performa DTR cartridges (Edge Biosystems). Complete sequences of the amplified IGS segments were obtained by primer walking using CN34, CN61, CNS12, RCN61, RU3, RU46.67, U46.67, and IGS4 (Table 1). To look for SNPs in the selected isolates (Table 1), a 568-bp portion of IGS rDNA was obtained using primers CN61 and U46.67 (Table 2). Sequencing was done by ELIM Biopharmaceuticals, Inc. using Big 
Dye chemistry (Applied Biosystems). IGS sequences were trimmed to the shortest common segment $(1,329 \mathrm{bp})$ and aligned using ClustalW 1.8 (31). Sequence identities were visualized using the GeneDoc Shading Utility 2.0.1 (Pittsburgh Supercomputing Center).

TaqMan real-time PCR assay. TaqMan PCR primers and a probe were designed using Primer Express (version 3.0; Applied Biosystems) based on the IGS sequence of Fus001 (GenBank FJ972801) and a putative G SNP for F. oxysporum f. sp. spinaciae identified in the aligned IGS sequences (see Results and Supplementary Figure 1), using default software parameters and the TaqMan minor groove binder option for the probe. Two reverse primers, FOS12 and FOS12A, were designed to amplify alternative reverse primer binding sites identified in the PNW isolates of $F$. oxysporum f. sp. spinaciae. Sequences of probe FOSP1, forward primer FOS1, and reverse primers FOS12 and FOS12A are shown in Table 2. The fluorochrome 6-carboxyfluorescein was attached to the $5^{\prime}$ terminus of the probe (TaqMan; Applied Biosystems) and the quencher dye tetra-methylcarboxyrhodamine was attached to the $3^{\prime}$ terminus.

Real-time PCR was performed in 50- $\mu$ l reactions, each containing $25 \mu \mathrm{l}$ of $2 \times$ Universal Master Mix (Applied Biosystems), 900 $\mathrm{nM}$ each of FOS1 and FOS12A or FOS12 + FOS12A, $250 \mathrm{nM}$ FOSP1 probe, and $5 \mu \mathrm{l}$ of mycelial DNA extract or $2 \mu \mathrm{l}$ of soil DNA extract. Amplification was done using an ABI 7300 real-time thermocycler (Applied Biosystems) at $95^{\circ} \mathrm{C}$ for $10 \mathrm{~min}$, followed by 40 cycles of $95^{\circ} \mathrm{C}$ for $15 \mathrm{~s}$ and $60^{\circ} \mathrm{C}$ for $1 \mathrm{~min}$. Negative control samples included water (no DNA) and 0.5 to $1.0 \mathrm{ng}$ of DNA from F. oxysporum f. sp. pisi isolate Fop1 (Table 1). DNA (approximately $50 \mathrm{pg}$ ) from each of $F$. oxysporum f. sp. spinaciae isolates Fus004 and Fus059 served as positive control samples. Each sample was assayed in duplicate.

TaqMan real-time PCR assay specificity. Specificity of the TaqMan real-time PCR assay was tested using DNA from $27 F$. oxysporum f. sp. spinaciae isolates (Table 1), 55 non-spinaciae isolates of $F$. oxysporum (Table 1), and 31 isolates of oomycetes and fungi other than $F$. oxysporum (Supplementary Table 1). DNA (1.0 to $2.5 \mathrm{ng}$ ) was extracted from mycelium of each isolate as described above or supplied by other researchers. Fop1 and Fus004 served as negative and positive DNA control samples, respectively. Cycle threshold $\left(\mathrm{C}_{\mathrm{t}}\right)$ values of 38.00 were considered the threshold for quantification based on preliminary assays that demonstrated that amplification of the target DNA at higher $C_{t}$ values was too variable to extrapolate pathogen quantity from duplicate PCR reactions (data not shown) (i.e., $\mathrm{C}_{\mathrm{t}}$ values $>38.00$ indicated nonspecific amplification). BLASTN (1) was used to query the GenBank non- redundant nucleotide database for sequence similarities to the realtime PCR assay primers and probe.

To test specificity of the assay with other formae speciales of $F$. oxysporum and other Fusarium spp. that could not readily be acquired, an in silico analysis of duplex stability $(\Delta \mathrm{G})(52)$ between the primers or probe and nontarget DNA templates was performed (Supplementary Table 2) using the nearest-neighbor algorithm of PrimerSelect 5.00 (DNASTAR, Inc.). Duplex stability values for IGS sequences of 53 accessions of Fusarium from GenBank and either FOS1, FOS12, or FOSP1 were obtained using default parameters of $50 \mathrm{mM}$ salt (common in PCR reaction buffers), $25^{\circ} \mathrm{C}$, and an average stability cut-off of $0.76 \mathrm{kcal} / \mathrm{mol} / \mathrm{bp}$. F. oxysporum f. sp. spinaciae isolates Fus001, NRRL26871, and Ky-2 served as positive control sequences; isolates Fus066 and Fus068 from pea were negative control sequences.

Mycelial and soil standard curves. Standard curves for DNA isolated from mycelia of fungal isolates were generated using 0.01 , $0.1,1.0,10,100$, and $1,000 \mathrm{pg}$ of DNA of $F$. oxysporum $\mathrm{f}$. sp. spinaciae Fus004 (for FOS12A genotype) and Fus059 (for FOS12 genotype), or a 1:1 mass ratio of DNA from Fus001 and Fus059 (for FOS12 + FOS12A mix) (Table 3). Fus001 and Fus004, having identical primer and probe binding sites, were used interchangeably in the real-time PCR assays. Soil was air dried, sieved (2-mmdiameter pore size), and used to generate two types of standard curves: (i) DNA extracts of a pathogen-free, Puget silt loam soil from Mount Vernon, WA (52) that was spiked with DNA of Fus004 $(0.6 \mathrm{pg}$ to $60 \mathrm{ng})$ and (ii) DNA extracts from a Mount Vernon soil inoculated at 10 -fold concentrations ranging from 10 to approximately $10,000 \mathrm{CFU} / \mathrm{g}$ with mycelium of Fus001, Fus003, or Fus004 or a mixture of equal populations of Fus004 and Fus059.

Naturally infested soils from spinach production sites and disease severity data. The TaqMan real-time PCR assay was evaluated using soil sampled from Washington spinach seed production sites representing a total of 82 samples collected from fields in northwestern Washington with a history of spinach Fusarium wilt: (i) samples designated "SV" collected from growercooperator fields $(n=9)$ in Skagit County, WA in 2008, representing a range of 1 to 15 years of rotation out of spinach seed crops (Table 4); (ii) samples $(n=20)$ collected from replicated plots in a 2008 spinach seed crop trial located in Skagit County, WA ('08SPFWLA') and planted to spinach inbred lines that ranged from highly susceptible to moderately resistant to Fusarium wilt (14; Table 5); (iii) samples $(n=24)$ collected from plots in a 2009 spinach trial located in a Skagit County field ('09SPFWLA') (24; Table 5); and (iv) soil $(n=29)$ collected in 2009 and 2010 from fields in Island, Skagit, Snohomish, and Whatcom Counties in

Table 2. Primers used to develop a TaqMan real-time polymerase chain reaction (PCR) assay for Fusarium oxysporum f. sp. spinaciae based on the intergenic spacer (IGS) region of ribosomal DNA

\begin{tabular}{|c|c|c|c|}
\hline Oligonucleotide & Sequence $\left(5^{\prime}\right.$ to $\left.3^{\prime}\right)$ & $\mathbf{n t}^{\mathbf{a}}$ & Reference \\
\hline \multicolumn{4}{|l|}{ For IGS sequencing } \\
\hline CNL12 & TGAACGCCTCTAAGTCAG & $28 \mathrm{~S}$ & 3 \\
\hline CN61 & GGTTCAATTTGATGTCGGCT & 482 & 48 \\
\hline RCN61 & AGCCGACATCAAATTGACC & 501 & 48 \\
\hline RU46.67 & GTGTCGGCGTGCTTGTATT & 987 & 48 \\
\hline U46.67 & AATACAAGCACGCCGACAC & 1,005 & 5 \\
\hline RU3 & GTGTGAAATTGGAAAGTCGG & 1,408 & 48 \\
\hline CN34 & CCAACACATGGGTGGTACCG & 1,493 & 48 \\
\hline $\mathrm{CNS} 12$ & GCACGCCAGGACTGCCTCGT & 1,898 & 48 \\
\hline IGSF4 & CCAGACTTCCACTGCGTGTC & 2,023 & 48 \\
\hline CNS1 & GAGACAAGCATATGACTACTG & $18 \mathrm{~S}$ & 59 \\
\hline \multicolumn{4}{|l|}{ For TaqMan assayb } \\
\hline FOS1 (forward) & GCTGGCGGATCTGACACTGT & 586 & This study \\
\hline FOS12 (reverse) & CAACCCGGCGAGGACGAA & 658 & This study \\
\hline FOS12A (reverse) & CAACCTGGCGAGGACGAA & 658 & This study \\
\hline FOSP1 (probe) & AACGAḠGTGCGAGCG & 609 & This study \\
\hline
\end{tabular}

\footnotetext{
a 5 ' nucleotide position in GenBank FJ972801 for reference isolate Fus001 of F. oxysporum f. sp. spinaciae (see Table 1).
}

${ }^{\mathrm{b}}$ For TaqMan real-time PCR assay. Underlined bases correspond to the adenine/guanine (A/G) genotypes in the FOS12 and FOS12A reverse primer binding sites, as well as the $\mathrm{G}$ single-nucleotide polymorphism identified as putatively unique to isolates of $F$. oxysporum $\mathrm{f}$. sp. spinaciae and used to design the TaqMan probe FOSP1. 
northwestern Washington ('10SPFWSB') (25; Table 5), with severity of spinach Fusarium wilt ranging from 0 to $100 \%$ (25). In the 2008 and 2009 spinach trials, incidence of plants with wilt symptoms was rated regularly through the season, spinach biomass and seed yield were measured, and the amount of $F$. oxysporum in the soil in each plot at harvest was quantified by plating soil samples onto Komada's agar medium $(14,24)$. In the bioassay of 29 fields sampled in 2009 and 2010, severity of Fusarium wilt was rated weekly, spinach biomass measured, and $F$. oxysporum enumerated on Komada's agar medium for each soil sample (25). Negative control soil samples were obtained from a field in the Columbia Basin of central Washington (VSP\#08-19) that had never been planted to spinach but was naturally infested with $F$. oxysporum f. sp. raphani $(13,19)$, and from a nonagricultural site near Quincy, WA (QV).

Statistical analyses. Data for the pathogenicity tests of fungal isolates were subjected to analyses of variance in Proc GLM of SAS (version 9.1; SAS Institute) for an RCBD with replicates (blocks) as a random variable and fungal isolates as a fixed variable. Fisher's protected least significant difference $(P<0.05)$ was used for comparing mean disease rating of isolates with those of the positive and negative control treatments. Real-time PCR assay results were compared using DNA extractions done in triplicate for each soil sample. Average $C_{t}$ values for each extract were obtained from duplicate PCR assays. All means and standard errors of $\mathrm{C}_{\mathrm{t}}$ values and, hence, picograms or CFU/g of soil, represented the average of three soil extractions per sample. Pearson's correlation coefficients were calculated for $F$. oxysporum f. sp. spinaciae $\mathrm{CFU} / \mathrm{g}$ of soil from the real-time PCR assays, total F. oxysporum/g of soil enumerated on Komada's agar medium, incidence or severity of Fusarium wilt, and spinach biomass, as detailed in the original reports $(14,24,25)$.

\section{Results}

Spinach pathogenicity tests. Symptoms of Fusarium wilt were observed on all plants inoculated with the control isolate of $F$. oxysporum f. sp. spinaciae, Fus001, in each pathogenicity test. Symptoms were first observed approximately 2 weeks after inoculation, as flaccid lower leaves, and progressed to chlorosis and necrosis of an increasing percentage of the leaves each week, with $100 \%$ severity by 3 to 4 weeks after inoculation and death of some plants by 5 to 6 weeks after inoculation. All of the noninoculated control plants remained asymptomatic over the duration of each pathogenicity test. Of 21 spinach isolates of $F$. oxysporum obtained from the PNW in this study and tested for pathogenicity on spinach, 18 caused Fusarium wilt symptoms in both pathogenicity tests, and 3 (VSP08-41-1, VSP08-41-5, and 502A\#2) did not cause symptoms in either test (Table 1). Results were consistent in the repeat pathogenicity test (data not shown). Some pathogenic isolates caused symptoms to develop as rapidly as those caused by Fus001, whereas other isolates appeared to be less aggressive because symptoms developed more slowly. Interestingly, F. oxysporum was reisolated from the roots of plants inoculated with each of the spinach isolates, regardless of whether the isolate was pathogenic or not on spinach; $F$. oxysporum was not isolated from the noninoculated control plants.

Similarly, pathogenicity to spinach was confirmed for 12 isolates of F. oxysporum f. sp. spinaciae obtained from Arkansas, California, Oklahoma, Tennessee, and Washington and 3 isolates from Japan collected previously (21), verifying the designation of these isolates as F. oxysporum f. sp. spinaciae (Table 1). Pathogenicity tests with four isolates of $F$. oxysporum obtained from Kawabe et al. (39) showed that only the spinaciae isolate (Ky-2) was pathogenic on spinach, whereas isolates of apii, cucumerinum, and matthiolae were not pathogenic on spinach (Table 1). Similarly, none of the six PNW isolates of F. oxysporum f. sp. raphani was pathogenic on spinach (Table 1).

Table 4. Quantification using a TaqMan real-time polymerase chain reaction assay of DNA of Fusarium oxysporum f. sp. spinaciae in soils sampled from nine fields in northwestern Washington that had previously been planted to spinach seed crops, and from two fields in central Washington that had never been planted to spinach seed crops

\begin{tabular}{lcccc}
\hline & \multirow{2}{*}{$\begin{array}{c}\text { Year } \\
\text { Field }\end{array}$} & & \multicolumn{2}{c}{ CFU/g of soil detected } \\
\cline { 4 - 5 } sampled $^{\mathbf{a}}$ & Planted $^{\mathbf{b}}$ & FOS12A & FOS12+12A $^{\text {nonyy}}$ \\
\hline SVE & 2008 & 2007 & $27.4 \pm 1.8$ & $24.8 \pm 11.3$ \\
SVF & 2008 & 2002 & $64.5 \pm 33.1$ & $72.0 \pm 22.6$ \\
SVR & 2008 & 1998 & $17.8 \pm 9.0$ & $18.3 \pm 5.6$ \\
SVW & 2008 & 1992 & $19.1 \pm 9.1$ & $28.2 \pm 3.2$ \\
SVK & 2008 & 1994 & $6.8 \pm 6.7$ & $13.2 \pm 6.0$ \\
SVK-A & 2009 & 2009 & $11.0 \pm 3.9$ & $25.6 \pm 10.6$ \\
SVK-B & 2009 & 2009 & $81.9 \pm 25.8$ & $126.0 \pm 49.0$ \\
SVB-N & 2010 & 2009 & $9.2 \pm 7.6$ & $14.4 \pm 12.4$ \\
SVB-S & 2010 & 2009 & $12.5 \pm 10.5$ & $5.8 \pm 3.1$ \\
VSP\#08-19c $^{c}$ & 2008 & Never & 0 & n.t. \\
QV $^{c}$ & 2008 & Never & 0 & n.t. \\
\hline
\end{tabular}

${ }^{a}$ Mean and standard error of three DNA extractions/soil sample. Reverse primers were used in combination with forward primer FOS1 to detect either the adenine $(A)$ or adenine + guanine $(A+G)$ versions of the single-nucleotide polymorphism detected in the intergenic spacer region of rDNA of F. oxysporum f. sp. spinaciae, using primer FOS12A only or primers FOS12 + FOS12A, respectively (see Table 2); n.t. = not tested.

b Year last planted to a spinach seed crop.

c Soil samples VSP\#08-19 and QV were from fields located near Quincy in central Washington, a semi-arid region outside of the maritime northwestern region of Washington where spinach seed crops are grown. These fields served as negative control samples (not infested with $F$. oxysporum f. sp. spinaciae).

Table 3. Standard curve constants for a TaqMan real-time polymerase chain reaction (PCR) assay for the spinach Fusarium wilt pathogen, Fusarium oxysporum f. sp. spinaciae, tested on DNA extracts from mycelium, inoculated soil, and clean soil extracts spiked with DNA of the pathogen

\begin{tabular}{|c|c|c|c|c|c|c|c|}
\hline \multirow[b]{2}{*}{ Substrate for extraction } & \multirow[b]{2}{*}{ Reverse primer ${ }^{b}$} & \multirow[b]{2}{*}{ Isolate } & \multirow[b]{2}{*}{ DNA template units ${ }^{c}$} & \multicolumn{3}{|c|}{ Standard curve constants ${ }^{a}$} & \multirow[b]{2}{*}{ Efficiency $^{\mathrm{d}}$} \\
\hline & & & & $m$ & $b$ & $R^{2}$ & \\
\hline \multirow[t]{3}{*}{ Mycelium } & FOS12A & Fus004 & pg DNA & -3.287 & 30.24 & 1.00 & 1.01 \\
\hline & FOS12 & Fus059 & pg DNA & -3.442 & 26.42 & 1.00 & 0.95 \\
\hline & $\mathrm{FOS} 12+12 \mathrm{~A}$ & Fus001+Fus059 & pg DNA & -3.229 & 30.1 & 1.00 & 1.04 \\
\hline \multirow[t]{2}{*}{ Inoculated soil } & FOS12A & Fus001+Fus003+Fus004 & $\mathrm{CFU} / \mathrm{g}$ & -3.384 & 40.21 & 0.97 & 0.97 \\
\hline & $\mathrm{FOS} 12+12 \mathrm{~A}$ & Fus004+Fus059 & $\mathrm{CFU} / \mathrm{g}$ & -3.295 & 42.45 & 0.92 & 1.01 \\
\hline Spiked soil extract & FOS12A & Fus004 & pg DNA & -3.277 & 23.46 & 0.97 & 1.02 \\
\hline
\end{tabular}

${ }^{a}$ Slope $(m)$ and $y$-intercept $(b)$ from plots of the mean cycle threshold values ( $y$-axis) for two to three replicated reactions or samples versus log fungal template DNA ( $x$-axis), where $y=m x+b ; R^{2}=$ coefficient of determination. Refer to the main text for details on the DNA extraction protocol from mycelium and soil.

${ }^{b}$ Each primer $(200 \mathrm{nM})$ was used in each real-time TaqMan PCR assay in combination with the forward primer, FOS1. Refer to Table 2 for details of the primers.

${ }^{c}$ Mycelial DNA in the PCR reaction $=0.01,0.1,1.0,10,100$, and 1,000 pg of DNA; the FOS12 + FOS12A reactions contained a 1:1 mass ratio of DNA from isolates Fus001 and Fus059 of F. oxysporum f. sp. spinaciae for a total of 0.01 to 1,000 pg of DNA. Inoculated soil contained Fus001 at 10, 40, 85, 420, 840, 4,200, and 8,400 CFU/g soil; Fus003 at 10, 45, 90, 440, 880, 4,400, and 8,800 CFU/g soil; and Fus004 at 10, 50, 95, 470, 940, 4,700, and 9,400 CFU/g soil. Fus001, Fus003, Fus004, and Fus059 are known pathogenic isolates of $F$. oxysporum f. sp. spinaciae. Spiked soil extract $=$ Fusarium-free soil DNA extract to which was added $0.6,6.0,60$, and $600 \mathrm{pg}$ and 6.0 and $60 \mathrm{ng}$ of Fus004 DNA for each reaction.

d Amplification efficiency $=10^{(1 /-m)}-1$, where $\mathrm{m}=$ slope of the standard curve $(26)$. 
G SNP common among spinach isolates. IGS amplicons of 1,329 to $2,499 \mathrm{bp}$ were obtained from $22 \mathrm{PNW} F$. oxysporum isolates originating from seven host species (GenBank accession numbers in Table 1). ClustalW analysis (31) indicated that the 22 sequences shared 96 to $99 \%$ sequence identity, with as much diversity among isolates of $F$. oxysporum $\mathrm{f}$. sp. spinaciae as among isolates of spinaciae and other formae speciales. The initial sequence comparison indicated that a real-time PCR assay for $F$. oxysporum f. sp. spinaciae could be based on a SNP in the IGS region (Fig. 1). All 34 isolates that were verified as $F$. oxysporum $\mathrm{f}$. sp. spinaciae by pathogenicity testing (20 from the PNW, 10 from other regions of the United States, and 4 from Japan; see above), as well as 2 spinach isolates designated as $F$. oxysporum f. sp. spinaciae by the suppliers (isolates FRC O-1136 and NRRL 26871), harbored a $\mathrm{G}$ residue at the equivalent nucleotide position 615 of the Fus001 IGS sequence (GenBank FJ972801). Of the three spinach isolates that were not pathogenic on the spinach inbred line 9420.553, one contained the G SNP and two had an adenine (A) at this nucleotide position (Table 1). Sixty-four additional isolates representing 24 formae speciales other than spinaciae had an A at position 615 (Table 1). This G SNP was the basis for designing the TaqMan probe, FOSP1 (Fig. 1).

TaqMan assay primers and specificity. A second G/A polymorphism was detected within the reverse primer binding site corresponding to nucleotide position 653 of the Fus001 IGS sequence (Fig. 1). Of 19 PNW isolates of $F$. oxysporum f. sp. spinaciae, $11(58 \%)$ had a $\mathrm{G}$ residue at nucleotide position 653 and $8(42 \%)$ had an A residue. Among the isolates from other states, $46 \%$ had a $\mathrm{G}$ nucleotide and $54 \%$ an A nucleotide at this location. However, the 33 isolates from Japan were predominantly the A genotype (85\%). Therefore, real-time PCR assays were developed using a mix of reverse primers for the G/A genotypes (FOS12 + FOS 12A) and for the A genotype alone (FOS12A) (Table 2).

DNA from 30 isolates of $F$. oxysporum $\mathrm{f}$. sp. spinaciae known to be pathogenic to spinach and carrying the $G$ SNP produced $C_{t}$ values of 11.01 to 23.91, depending on the quantity of DNA used in the assay (Table 1). $C_{t}$ values of 38.00 were considered the threshold for quantification and $C_{t}$ values $>38.00$ were considered nonspecific, as described above. DNA from $F$. oxysporum isolates representing 26 other formae speciales yielded $C_{t}$ values $>38.00$ or failed to generate detectable fluorescence (Table 1). An additional
33 isolates representing 28 species other than $F$. oxysporum also did not produce the IGS amplicon. In total, 67 nontarget isolates either carried the A SNP or failed to produce an amplicon, demonstrating the specificity of the TaqMan assay for the $F$. oxysporum $\mathrm{f}$. sp. spinaciae isolates evaluated in this study.

In silico oligonucleotide-template duplex stability analysis, used to evaluate the likelihood of nonspecific primer or probe binding, demonstrated that the $\Delta \mathrm{G}$ values for specific target annealing were -38.6 and -37.7 for FOS1 and FOS12A, respectively, and -33.8 to $-32.8 \mathrm{kcal} / \mathrm{mol}$ for the probe FOSP1. These values reflected a high degree of duplex stability and were predictive of PCR amplification (Table 1). In contrast, the $\Delta \mathrm{G}$ values for the $F$. oxysporum $\mathrm{f}$. sp. pisi sequences, for example, indicated perfect duplex formation for only one of the two primers; other templates harbored imperfect FOS12 binding sites with less stable $\Delta \mathrm{G}$ values ( -28 to -34 $\mathrm{kcal} / \mathrm{mol}$ ), or were "null" (no predicted duplex formation). The $\Delta \mathrm{G}$ value for FOSP1 and templates with the A SNP was -28.4 $\mathrm{kcal} / \mathrm{mol}$. BLASTN analysis resulted in no nonspecific matches between FOS primers or probe and sequences in the nonredundant GenBank database.

G SNP in formae speciales other than $F$. oxysporum f. sp. spinaciae. Eleven $F$. oxysporum isolates from spinach that proved to be nonpathogenic when inoculated onto the proprietary spinach line 9420.553, or from hosts other than spinach, carried the G SNP based on nucleotide sequence analysis (Table 1), real-time PCR analysis (Table 1), or probe-template duplex stability analysis. The isolates included $F$. oxysporum ff. spp. apii, cucumerinum, lagenariae, lilii, matthiolae, melongenae, and raphani. Three of the Japanese isolates available for testing were also nonpathogenic to spinach line 9420.553, as described above. Among the U.S. isolates, one (VSP08-41-1) originated from PNW spinach seed crops and carried the G SNP but was nonpathogenic on line 9420.553 . Two other U.S. isolates carrying the G SNP were identified by the suppliers as $F$. oxysporum ff. spp. apii and lilii (Table 1). These results indicate potential cross-reaction of the real-time PCR assay with a limited number of isolates of seven formae speciales other than spinaciae and with a nonpathogenic isolates of $F$. oxysporum that colonized spinach plants.

Further evaluation of cross-detection of the real-time PCR assay. As a result of cross-detection of the real-time PCR assay with the two nonpathogenic isolates of $F$. oxysporum obtained from

Table 5. Correlation coefficients of the amount of Fusarium oxysporum f. sp. spinaciae detected using a TaqMan real-time polymerase chain reaction (PCR) assay in soils sampled from fields in northwestern Washington versus the amount of $F$. oxysporum detected by soil dilution plating, the incidence or severity of spinach Fusarium wilt, and spinach biomass ${ }^{\mathrm{a}}$

\begin{tabular}{lccrc}
\hline Spinach Fusarium wilt trial & $\begin{array}{c}\text { Number of plots } \\
\text { or fields sampled }^{\mathbf{b}}\end{array}$ & $\begin{array}{c}\text { F. oxysporum } \\
\text { CFU/g of soil }\end{array}$ & $\begin{array}{c}\text { Incidence or severity of } \\
\text { Fusarium wilt }^{\mathbf{d}}\end{array}$ & $\begin{array}{c}\text { Spinach } \\
\text { dry biomass }^{\mathbf{e}}\end{array}$ \\
\hline 2008 field trial (08SPFWLA) & 20 plots & $0.7269(P=0.0003)$ & $-0.0491(P=0.8373)$ & $-0.0327(P=0.8910)$ \\
2009 field trial (09SPFWLA) & 24 plots & $0.9309(P<0.0001)$ & $0.0863(P=0.6886)$ & $-0.0026(P=0.9905)$ \\
2009-10 soil bioassay trial (10SPFWSB) & 29 fields & $0.4414(P=0.0272)$ & $0.5172(P=0.0096)$ & $-0.4034(P=0.0456)$ \\
\hline
\end{tabular}

${ }^{\text {a }}$ F. oxysporum f. sp. spinaciae CFU/g of soil calculated based on a TaqMan real-time PCR assay for DNA of the target pathogen, and quantified using a standard curve (refer to the main text and Table 2 for details). Numbers in parentheses are the probability $(P)$ of rejecting the null hypothesis of no significant correlation between those two variables.

${ }^{b}$ Each plot and field was naturally infested with the spinach Fusarium wilt pathogen following previous commercial spinach seed crops. Details of the 2008 trial are described by du Toit et al. (14), the 2009 trial by Gatch et al. (24), and the 2009-10 soil bioassay by Gatch and du Toit (25).

${ }^{c}$ Total F. oxysporum CFU/g of soil plated on Komada's agar medium (43). The agar medium does not permit differentiation of isolates of $F$. oxysporum f. sp. spinaciae from those of other formae speciales or nonpathogenic isolates.

${ }^{\mathrm{d}}$ Incidence or severity of spinach plants with Fusarium wilt was rated multiple times in each trial. Results are shown for ratings on 9 and 14 July in the 2008 and 2009 field trials, respectively; and a final severity rating 42 days after planting in the 2009-10 soil bioassay.

${ }^{\text {e }}$ Spinach dry biomass measured on 10 and 24 July in the 2008 and 2009 field trials, respectively; and 42 days after planting in the 2009-10 soil bioassay.

Fus001 GCTGGCGGATCTGACACTGTCGAAACGAGGTGCGAGCGGTGTAGGGTAGGCTAGTTTCGTCCTCGCCAGGTTG Fus059 GCTGGCGGATCTGACACTGTCGAAACGAGGTGCGAGCGGTGTAGGGTAGGCTAGTTTCGTCCTCGCCGGGTTG FOS1 FOSP1

FOS12/12A

Fig. 1. Primer and probe binding sites of the intergenic spacer region of ribosomal DNA of isolates Fus 001 and Fus 059 of Fusarium oxysporum f. sp. spinaciae, used to design a TaqMan real-time polymerase chain reaction (PCR) assay for the pathogen. Bold letters indicate a guanine single-nucleotide polymorphism in probe FOSP1, and an adenine/guanine polymorphism in the FOS12 reverse primer binding site for which two reverse primers were designed, FOS12 and FOS12A. Refer to the main text for details of the real-time PCR assay. 
spinach plants, an additional 38 isolates of $F$. oxysporum and 9 isolates of other Fusarium spp. obtained from spinach plants (with or without symptoms of Fusarium wilt), spinach seed, or soil sampled from fields that had been planted to spinach crops were tested for pathogenicity on spinach and tested using the real-time PCR assay. Inoculum of each isolate was produced in Kerr's broth as described above for the original pathogenicity tests. Instead of the spinach inbred 9420.553, a proprietary female spinach line was used that is highly susceptible to Fusarium wilt and has been evaluated for more than 5 years in spinach Fusarium wilt field trials in northwestern Washington (12-14,24). Seedlings were grown in 72cell flats as described above. Approximately 10 days after planting, the flats were cut into five sets of 12 cells (plants), and $4 \mathrm{ml}$ of a spore suspension $\left(5 \times 10^{5}\right.$ spores $\left./ \mathrm{ml}\right)$ of each of the fungal isolates was applied as a drench over the root plug of each of the 12 plants (replications) using a 10-ml syringe. A different syringe was used for each fungal isolate. Fus001 was inoculated similarly as a positive control treatment and water was used as a negative control treatment. The seedlings were rated weekly for symptoms of Fusarium wilt until 35 days after planting, and the data were analyzed as described above. Nine of the $F$. oxysporum isolates associated with spinach and listed in Table 1 (six pathogenic isolates: Fus193, Fus194, Fus253, Fus258, Fus261, and 404ABmaleA; and three nonpathogenic isolates: VSP08-41-1, VSP08-41-5, and $502 \mathrm{A \# 2}$ ) were tested again for pathogenicity in this assay.

Of the 38 additional isolates of $F$. oxysporum tested, 20 were pathogenic and 18 were not pathogenic on spinach (data not shown). All 20 pathogenic isolates tested positive for $F$. oxysporum f. sp. spinaciae using the real-time PCR assay (true positive results). However, of the 18 nonpathogenic isolates, 4 (22.2\%) tested negative with the real-time PCR assay (true-negative results), and $14(77.7 \%)$ tested positive with the real-time PCR assay (falsepositive results for the real-time PCR assay). There were no falsenegative results (i.e., none of the pathogenic isolates tested negative with the real-time PCR assay). Of the nine $F$. oxysporum isolates shown in Table 1 that were retested for pathogenicity on spinach using the drench inoculation, results were consistent with the original pathogenicity tests (i.e., six were pathogenic and three were nonpathogenic). All nine isolates of other Fusarium spp. tested negative for pathogenicity and negative with the real-time PCR assay, illustrating specificity of the real-time PCR assay for isolates of $F$. oxysporum. The species identity of each of the 18 nonpathogenic isolates of $F$. oxysporum was confirmed by sequencing the ITS rDNA in both directions, aligning the sequences, and determining the closest matching sequences in GenBank (data not shown).

Pathogen quantification in soil samples. Amplification efficiencies derived from all soil standard curves were between 0.95 and 1.02 (Table 3), indicating that the TaqMan real-time PCR assay amplified at least $95 \%$ of the target sequences in the soil DNA extracts. Detection limits of the assays, extrapolated at the empirical quantification thresholds of $\mathrm{a} \mathrm{C}_{t}$ of 39.00 and 38.00 for soil and mycelial extracts, respectively, were estimated to be $2 \mathrm{CFU} / \mathrm{g}$ for soil samples assayed using reverse primer FOS12A alone, and 11 $\mathrm{CFU} / \mathrm{g}$ soil using FOS12 + FOS12A. Attempts to generate high concentrations of chlamydospores of Fus001, Fus003, and Fus004 to test soil DNA extraction from these persistent pathogen propagules were unsuccessful. However, the protocol used for soil DNA extraction successfully amplified target DNA from dried soil samples, which most likely contained chlamydospores. For seven of the nine soil samples tested from fields in Skagit County, WA that had been rotated out of spinach seed crops for durations ranging from 1 to 15 years, the real-time PCR assay detected $F$. oxysporum f. sp. spinaciae in all nine fields, at populations of $5.8 \pm 3.1$ to $126.0 \pm 49.0 \mathrm{CFU} / \mathrm{g}$ of soil (Table 4). In contrast, the two control soil samples collected from fields in central Washington that had never been planted to spinach did not show detectable levels of the pathogen (Table 4). The assay detected $F$. oxysporum f. sp. spinaciae at as little as $6.8 \pm 6.7$ to $13.2 \pm 6.0 \mathrm{CFU} / \mathrm{g}$ of soil in a field in northwestern Washington that had been rotated out of spinach for
15 years. Slightly greater populations were detected in eight of the nine fields when the real-time PCR assay was done using the FOS12 + FOS12A primer mix compared with FOS12A alone (Table 4), indicating that both $\mathrm{G}$ and $\mathrm{A}$ genotypes of the pathogen were present in these soil samples. However, the differences in populations detected with the two forms of the real-time PCR assay were typically less than the standard deviation of the mean for each assay of a particular field.

Comparison of the TaqMan real-time PCR assay with soil dilution plating. TaqMan real-time PCR assays of 20 soil samples collected from a 2008 spinach field trial generated $F$. oxysporum $\mathrm{f}$. sp. spinaciae at 4 to $2,269 \mathrm{CFU} / \mathrm{g}$ of soil (mean of $124 \mathrm{CFU} / \mathrm{g}$ ) and, of 24 soil samples collected from the 2009 field trial, 7 to $14,056 \mathrm{CFU} / \mathrm{g}$ of soil (mean of $674 \mathrm{CFU} / \mathrm{g}$ ). Quantification of $F$. oxysporum f. sp. spinaciae using the real-time PCR assay showed significant $(P<0.05)$ positive correlations with total $F$. oxysporum $\mathrm{CFU} / \mathrm{g}$ of soil enumerated by dilution plating onto Komada's agar medium for the 73 soil samples collected from fields in northwestern Washington from 2008 to 2010 (Table 5). The strongest correlation was for soils sampled from the 2009 spinach trial plots $(r=$ 0.9309 at $P<0.0001$ ), followed by soils from the 2008 trial plots ( $r=0.7269$ at $P=0.0003$ ), and 29 fields sampled in the 2009-10 bioassay ( $r=0.4414$ at $P=0.0272$ ). However, for both the 2008 and 2009 field trials, there was no significant correlation between F. oxysporum $\mathrm{f}$. sp. spinaciae $\mathrm{CFU} / \mathrm{g}$ of soil quantified using the real-time PCR assay and either the incidence of Fusarium wilt (percentage of plants with symptoms of Fusarium wilt) or spinach dry biomass (Table 5). In contrast, for the 2009-10 soil bioassay trial, CFU/g of soil quantified using the real-time PCR assay was significantly positively correlated with severity of spinach Fusarium wilt $(r=0.5172$ at $P=0.0096)$ and significantly negatively correlated with spinach biomass $(r=-0.4034$ at $P=$ 0.0456) (Table 5).

\section{Discussion}

The TaqMan real-time PCR assay developed in this study was based on a G SNP common to the IGS rDNA of all 36 of the original isolates of $F$. oxysporum $\mathrm{f}$. sp. spinaciae evaluated, regardless of the state or country of origin. IGS sequence diversity at the G position was anticipated based on published reports for other formae speciales of $F$. oxysporum $(36,37,57)$. The detection and quantification of $F$. oxysporum $\mathrm{f}$. sp. spinaciae DNA in a subset of soils from nine fields in northwestern Washington with a history of spinach seed production but not in soils from two fields in central Washington with no history of spinach production indicated that the real-time PCR assay could be a useful tool for assessing pathogen populations in soils. One field that had been planted to a spinach seed crop 15 years prior to collecting soil samples still harbored quantifiable $F$. oxysporum $\mathrm{f}$. sp. spinaciae DNA when tested with the real-time PCR assay. This supports empirical observations (L. J. du Toit, personal observation) that the pathogen can be extremely persistent in soils in the maritime PNW, and that a rotation interval of 15 years may not be adequate for avoiding losses to spinach Fusarium wilt in some fields, depending on the susceptibility to Fusarium wilt of the parent lines that a seed grower is contracted to plant $(12,22)$. The real-time PCR assay detected $F$. oxysporum f. sp. spinaciae in a field that had been rotated out of spinach production since 1994 . When that field was planted to a spinach seed crop in 2008 , the crop succumbed to a very severe outbreak of Fusarium wilt, resulting in a major loss to the grower and seed company (L. J. du Toit, personal observation), which concurred with detection of the pathogen using the real-time PCR assay.

Further evaluation of the TaqMan real-time PCR assay as a tool for predicting the risk of spinach Fusarium wilt was done by testing naturally infested soils from three spinach field trial sites in northwestern Washington. A significantly positive correlation of $F$. oxysporum f. sp. spinaciae CFU detected with the real-time PCR assay versus $F$. oxysporum $\mathrm{CFU}$ detected by serial dilutions of soil on Komada's agar was observed for all three trials, even though 
isolates of $F$. oxysporum $\mathrm{f}$. sp. spinaciae cannot be differentiated from isolates of other formae speciales on Komada's agar medium (43). Enumeration of the spinach wilt pathogen using the real-time PCR assay was also significantly positively correlated with severity of Fusarium wilt and significantly negatively correlated with spinach dry biomass in soils sampled from 29 fields in northwestern Washington in 2009-10. In contrast, there was no significant correlation between pathogen population and disease incidence for soils sampled from plots in separate field trials in each of 2008 and 2009 in northwestern Washington. This might have been due to the confounding presence of another soilborne vascular wilt pathogen, Verticillium dahliae, detected in soils from these sites $(14,15,24)$. Furthermore, development of Fusarium wilt in spinach seed crops is strongly influenced by the susceptibility of spinach cultivars or inbred lines $(12,14)$, as well as by crops rotated with spinach, rotation intervals between spinach seed crops, soil properties $(22,25)$, and other factors. Lack of uniformity in distribution of $F$. oxysporum f. sp. spinaciae within infested fields and the limited volume of soil (up to $0.8 \mathrm{~g}$ ) used for each DNA extraction for the real-time PCR assay could also introduce sampling errors. Further confounding this is the evidence of a high level of cross-detection by the real-time PCR assay of nonpathogenic isolates of $F$. oxysporum associated with spinach plants or with soil sampled from fields planted to spinach (16 of 22 nonpathogenic isolates evaluated in this study tested positive with the real-time PCR assay). These factors limit utility of the real-time PCR assay for accurately predicting the risk of spinach Fusarium wilt for specific fields, as is true for any soil assay based strictly on pathogen quantification.

F. oxysporum consists of a collection of diverse formae speciales defined principally by substrate or host of origin. In this study, six F. oxysporum isolates from Japan designated as formae speciales apii, cucumerinum, matthiolae, melongenae, niveum, and fragariae clustered with those of $F$. oxysporum f. sp. spinaciae (39) in phylogenetic analysis of the IGS region, suggesting that IGS sequence similarity is not strictly correlated to host substrate (host species). This was supported by evidence of the G SNP being present in a few isolates from seven formae speciales other than spinaciae, five of which were confirmed to be nonpathogenic on spinach using pathogenicity assays; the remaining two were not available for pathogenicity testing. One additional isolate with the G SNP and obtained from spinach plants with symptoms of Fusarium wilt could not be designated as f. sp. spinaciae based on the pathogenicity tests, demonstrating the need to test isolates for accurate formae speciales designation, even isolates obtained from plants with typical Fusarium wilt symptoms. In other studies, phylogenetic clustering based on sequences of IGS rDNA and the mating type locus, MATl, placed some isolates of $F$. oxysporum f. sp. spinaciae with isolates of the ff. spp. niveum, cubense, lycopersici, radicis-lycopersici (42), and ciceris $(36,37,39,42)$. The studies suggest that host pathogenicity may be evolving independently of the IGS and MAT1 loci $(39,57)$ for isolates of these formae speciales, which may hamper IGS-based identification and quantification of F. oxysporum f. sp. spinaciae.

Molecular diversity has been reported at the IGS region of isolates of $F$. oxysporum f. sp. melonis (5). RAPD markers were used to differentiate yellowing and wilting pathotypes of $F$. oxysporum f. sp. ciceris, as well as isolates of pathogenic races $0,1 \mathrm{~B} / \mathrm{C}, 5$, and 6 (36,37). Similarly, diversity for isolates of $F$. oxysporum f. sp. lycopersici (57) suggests that host range or virulence determinants arise independently of and more rapidly than changes at the IGS and other regions of DNA within different genotypes (27), possibly by horizontal gene transfer $(47,57)$. Phylogenetic associations can be complicated by the presence of more than one IGS sequence within a single isolate (5), by spontaneous loss of pathogenicity, and by sequestration on nonhost substrates (23). Dual host pathogenicity has also been observed for several isolates of $F$. oxysporum f. sp. spinaciae from western Washington that proved to be pathogenic on sugar beet (Beta vulgaris subsp. vulgaris) in greenhouse pathogenicity tests (32). Following initial pathogenicity tests in this study, it was discovered that the spinach line used for the pathogenicity tests had a low level of partial resistance to Fusarium wilt. Although there is no known "complete" resistance to Fusarium wilt in spinach germplasm, and resistance appears to be quantitative (J. Schafer and J. de Visser, spinach breeders, personal communication), inadvertent use of a parent line with partial resistance to $F$. oxysporum f. sp. spinaciae may have precluded identification of the correct forma specialis of weakly aggressive isolates of the pathogen. However, subsequent pathogenicity testing using a female spinach line that is highly susceptible to Fusarium wilt corroborated results of the initial pathogenicity tests.

The significant incidence of cross-detection of the real-time PCR assay developed for $F$. oxysporum $\mathrm{f}$. sp. spinaciae with nonpathogenic isolates of $F$. oxysporum obtained from spinach plants, seed, and soil sampled from fields in which spinach had been grown was unexpected. Although speculative, one hypothesis for similarity of the SNP in pathogenic and nonpathogenic isolates from spinach plants is a close genetic relationship between the isolates. Such a relationship has been observed within some other formae speciales $(2,4,27,38,47)$. However, further work would need to be conducted to address this hypothesis. Virulence factors governing tomato responses to $F$. oxysporum f. sp. lycopersici were demonstrated to reside on mobile pathogenicity chromosomes that are lineage specific (47). Transfer of portions of an effector-carrying chromosome from $F$. oxysporum f. sp. lycopersici to a nonpathogenic isolate rendered the recipient isolate pathogenic on tomato (47).

Isolates of $F$. oxysporum formae speciales other than spinaciae also may pose complications for accurate quantification of $F$. oxysporum f. sp. spinaciae using the real-time PCR assay developed in this study. Based on information received from the Fusarium Research Center (Pennsylvania State University), isolate O-0326 probably originated from Easter (trumpet) lily in California or Oregon (R. Linderman, personal communication). Although the isolate was obtained from a lily plant with symptoms of Fusarium wilt, the isolate does not appear to have been tested for pathogenicity on lily to verify the forma specialis designation, complicating efforts to assess specificity of molecular detection assays for isolates of different formae speciales of $F$. oxysporum, including the real-time PCR assay developed in this study. Nonetheless, PNW spinach seed production sites are seldom planted to lily crops. Likewise, celery and stock crops are not grown in rotation with spinach seed crops in the PNW; therefore, isolates of $F$. oxysporum f. sp. apii and matthiolae are not expected to interfere with use of the real-time PCR assay in the primary region of spinach seed production in the United States. However, F. oxysporum f. sp. cucumerinum does occur in this spinach seed production region. Furthermore, the Willamette Valley of western Oregon is an important region for both radish and spinach seed production. Combined with potential cross-detection of the real-time PCR assay with nonpathogenic isolates of $F$. oxysporum associated with spinach, this means that there is a potential for overestimating populations of $F$. oxysporum $\mathrm{f}$. sp. spinaciae using the real-time PCR assay. Similarly, use of the real-time PCR assay for testing spinach seed for $F$. oxysporum $\mathrm{f}$. sp. spinaciae may be confounded by potential cross-detection of nonpathogenic isolates of $F$. oxysporum that can be associated with spinach seed (unpublished data), and by the fact that such PCR assays cannot differentiate DNA from live versus dead cells of the target pathogen. This may result in overestimation of the amount of viable inoculum in seed lots, particularly lots that have been stored for extended periods or exposed to treatments such as hot water or chlorine (16).

The main limitation of the real-time PCR assay developed in this study for detection and enumeration of $F$. oxysporum f. sp. spinaciae is the potential for cross-detection of nonpathogenic isolates of $F$. oxysporum that are readily isolated from spinach plants or from soil in which spinach crops are grown. The incidence of cross-detection of nonpathogenic isolates was much greater than for other formae speciales. Therefore, investigation of the potential genetic relationship of nonpathogenic isolates of $F$. oxysporum 
with isolates pathogenic on spinach may be warranted, (e.g., using vegetative compatibility, mitochondrial DNA haplotyping, or IGS haplotyping; 27). Despite these limitations, the assay may provide a means of screening for resistance to Fusarium wilt of spinach (56) by enabling quantification of the pathogen in spinach plants inoculated with the pathogen.

\section{Acknowledgments}

This research was supported by the United States Department of Agriculture (USDA) Agricultural Research Service Project Number 5248-22000-012-00D (P. A. Okubara and K. L. Schroeder), a USDA Sustainable Agriculture Research and Education Graduate Student Fellow Grant, a USDA Western Region Integrated Pest Management Grant, CRIS Project WPN05595, and Washington State University CAHNRS, Agricultural Research Center, and Department of Plant Pathology (PPNS number 0563). We thank T. Gordon, M. Kawabe, and J. Leslie for valuable discussions; J. Correll, B. Pryor, L. Hanson, M. Kawabe, and other cooperators for fungal isolates or DNA extracts of fungal isolates; L. Carris, X. Chen, T. Friesen, N. Grünwald, D. Johnson, M. Mazzola, T. Murray, R. Smiley, and D. Weller for providing some non-Fusarium DNA; M. Derie, K. Coats, and G. Chastagner for providing TaqMan data on isolates from Fiely et al. (21); N. Walter, L. Hulbert, and K. Reed for assistance with sequencing and DNA extractions; and K. Reed, B. Holmes, and L. Brissey for assistance with pathogenicity testing.

\section{Literature Cited}

1. Altschul, S. F., Madden, T. L., Schaffer, A. A., Zhang, J., Zhang, Z., Miller, W., and Lipman, D. J. 1997. Gapped BLAST and PSI-BLAST: a new generation of protein database search programs. Nucleic Acids Res. 25:33893402 .

2. Alves-Santos, F. M., Benito, E. P., Eslava, A. P., and Diaz-Minguez, J. M. 1999. Genetic diversity of Fusarium oxysporum strains from common bean fields in Spain. Appl. Environ. Microbiol. 65:3335-3340.

3. Anderson, J. B., and Stasovski, E. 1992. Molecular phylogeny of Northern Hemisphere species of Armillaria. Mycologia 84:505-516

4. Appel, D. J., and Gordon, T. R. 1994. Local and regional variation in populations of Fusarium oxysporum from agricultural field soils. Phytopathology 84:786-791.

5. Appel, D. J., and Gordon, T. R. 1996. Relationships among pathogenic and nonpathogenic isolates of Fusarium oxysporum based on the partial sequence of the intergenic spacer region of the ribosomal DNA. Mol. PlantMicrobe Interact. 9:125-138.

6. Armstrong, G. M., and Armstrong, J. K. 1976. Common hosts for Fusarium oxysporum formae speciales spinaciae and betae. Phytopathology 66:542545

7. Baayen, R. P., O’Donnell, K., Bonants, P. J. M, Cigelnik, E., Kroon, L. P. N. M, Roebroeck, E. J. A., and Waalwijk, C. 2000. Gene genealogies and AFLP analyses in the Fusarium oxysporum complex identify monophyletic formae speciales causing wilt and rot disease. Phytopathology 90:891-900.

8. Beckman, C. H. 1987. The Nature of Wilt Diseases of Plants. American Phytopathological Society, St. Paul, MN.

9. Cai, G., Gale, L. R., Schneider, R. W., Kistler, H. C., David, R. M., Elias, K. S., and Miyao, E. M. 2003. Origin of race 3 of Fusarium oxysporum f. sp. lycopersici at a single site in California. Phytopathology 93:1014-1022.

10. Chef, D. G., Hoitink, H. A. J., and Madden, L. V. 1983. Effects of organic compounds in container media on suppression of Fusarium wilt of chrysanthemum and flax. Phytopathology 73:279-281.

11. Correll, J. C., Morelock, T. E., Black, M. C., Koike, S. T., Brandenberger, L. P., and Dainello, F. J. 1994. Economically important diseases of spinach. Plant Dis. 78:653-660.

12. du Toit, L. J., Derie, M. L., Brissey, L. M., and Cummings, J. A. 2007. Evaluation of limestone amendments for control of Fusarium wilt in a spinach seed crop, 2006. Plant Dis. Manage. Rep. 1:V091.

13. du Toit, L. J., Derie, M. L., Gatch, E. W., Alcala, A. C., Reed, K., and Holmes, B. J. 2011. Effect of agricultural limestone amendment on Fusarium wilt in a radish seed crop, 2010. Plant Dis. Manage. Rep. 5:ST001.

14. du Toit, L. J., Derie, M. L., Gatch, E. W., Brissey, L. M., and Holmes, B. J. 2011. Effect of agricultural limestone amendments on Fusarium and Verticillium wilts in a spinach seed crop, 2008. Plant Dis. Manage. Rep. 5:V117.

15. du Toit, L. J., Derie, M. L., and Hernandez-Perez, P. 2005. Verticillium wilt in spinach seed production. Plant Dis. 89:4-11

16. du Toit, L. J., and Hernandez-Perez, P. 2005. Efficacy of hot water and chlorine for eradication of Cladosporium variabile, Stemphylium botryosum, and Verticillium dahliae from spinach seed. Plant Dis. 89:1305-1312.

17. du Toit, L. J., Miller, T. W., Derie, M. L., Maupin, B. G., Peterson, R. K., and Libbey, C. 2004. Evaluation of mustard cover/biofumigant crops for management of Fusarium wilt in spinach seed crops, 2002-2003. Biol. Cult. Tests 19:V004.

18. du Toit, L. J., Miller, T. W., Libbey, C. R., Derie, M. L., and Peterson, R. K. 2006. Evaluation of mustard cover/biofumigant crops for management of Fusarium wilt in spinach seed crops, 2004-2005. Biol. Cult. Tests 21:V001.

19. du Toit, L. J., and Pelter, G. Q. 2003. Wilt of radish caused by Fusarium oxysporum f. sp. raphani in Washington State. Plant Health Progress. Online publication. doi:10.1094/PHP-2003-0616-01-HN

20. Enya, J., Togawa, M., Takeuchi, T., Yoshida, S., Tsushima, S., Arie T., and Sakai, T. 2008. Biological and phylogenetic characterization of Fusarium oxysporum complex, which causes yellows on Brassica spp., and proposal of F. oxysporum $\mathrm{f}$ sp. rapae, a novel forma specialis pathogenic to B. rapa in Japan. Phytopathology 98:475-483.

21. Fiely, M. B., Correll, J. C., and Morelock, T. E. 1995. Vegetative compatibility, pathogenicity, and virulence diversity of Fusarium oxysporum recovered from spinach. Plant Dis. 79:990-993.

22. Foss, C. R., and Jones, L. J. 2005. Crop Profile for Spinach Seed in Washington. U.S. Department of Agriculture National Pest Management Centers.

23. Fourie, G., Steenkamp, E. T., Ploetz, R. C., Gordon, T. R., and Viljoen, A 2011. Current status of the taxonomic position of Fusarium oxysporum formae specialis cubense within the Fusarium oxysporum complex. Infect. Gen. Evol. 11:533-542.

24. Gatch, E. W., Derie, M. L., Brissey, L. M., Holmes, B. J., and du Toit, L. J. 2011. Effect of agricultural limestone amendments and nitrogen source on Fusarium wilt in a spinach seed crop, 2009. Plant Dis. Manage. Rep. 5:V118.

25. Gatch, E. W., and du Toit, L. J. 2011. Development of a soil bioassay to assess the risk of spinach Fusarium wilt. (Abstr.) Phytopathology 101:S248.

26. Ginzinger, D. G. 2002. Gene quantification using real-time quantitative PCR: an emerging technology hits the mainstream. Exp. Hematol. 30:503512.

27. Gordon, T. R., and Martyn, R. D. 1997. The evolutionary biology of Fusarium oxysporum. Annu. Rev. Phytopathol. 35:111-128.

28. Haglund, W. A. 1989. A rapid method for inoculating pea seedlings with Fusarium oxysporum f. sp. pisi. Plant Dis. 73:457-458.

29. Hawksworth, D. L., Kirk, P. M., Sutton, B. C., and Pegler, D. N. 1995. Dictionary of the Fungi, 8th ed. CAB International, Wallingford, UK.

30. Hernandez-Perez, P., and du Toit, L. J. 2006. Seedborne Cladosporium variabile and Stemphylium botryosum in spinach. Plant Dis. 90:137-145.

31. Higgins, D., Thompson, J., Gibson, T., Thompson, J. D., Higgins, D. G., and Gibson, T. J. 1994. CLUSTAL W: Improving the sensitivity of progressive multiple sequence alignment through sequence weighting, position-specific gap penalties and weight matrix choice. Nucleic Acids Res. 22:4673-4680.

32. Hill, A. L., Reeves, P. A., Larson, R. L., Fenwick, A. L., Hanson, L. E., and Parella, L. 2011. Genetic variability among isolates of Fusarium oxysporum from sugar beet. Plant Pathol. 60:496-505.

33. Ito, S., Kawaguchi, T., Nagata, A., Tamura, H., Matsushita, H., Takahara, H., Tanaka, S., and Ikeda, T. 2004. Distribution of the FoTom1 gene encoding tomatinase in formae speciales of Fusarium oxysporum and identification of a novel tomatinase from $F$. oxysporum f. sp. radicis-lycopersici, the causal agent of Fusarium crown and root rot of tomato. J. Gen. Plant Pathol. 70:195-201.

34. Jiménez-Fernández, D., Montes-Borrego, M., Jiménez-Díaz, R. M., NavasCortés, J. A., and Landa, B. B. 2011. In planta and soil quantification of Fusarium oxysporum f. sp. ciceris and evaluation of Fusarium wilt resistance in chickpea with a newly developed quantitative polymerase chain reaction assay. Phytopathology 101:250-262.

35. Jiménez-Gasco, M. M., and Jiménez-Díaz, R.M. 2003. Development of a specific polymerase chain reaction-base assay for the identification of $F u$ sarium oxysporum $\mathrm{f}$. sp. ciceris and its pathogenic races $0,1 \mathrm{~A}, 5$, and 6 . Phytopathology 93:200-209.

36. Jiménez-Gasco, M. M., Milgroom, M. G., and Jiménez-Díaz, R. M. 2004 Stepwise evolution of races in Fusarium oxysporum f. sp. ciceris inferred from fingerprinting with repetitive DNA sequences. Phytopathology 94:228-235.

37. Jiménez-Gasco, M. M., Navas-Cortés, J.A., and Jiménez-Díaz, R. M. 2004. The Fusarium oxysporum f. sp. ciceris/Cicer arietinum pathosystem: A case study of the evolution of plant-pathogenic fungi into races and pathotypes. Int. Microbiol. 7:95-104.

38. Katan, T., Katan, J., Gordon, T. R., and Pozniak, D. 1994. Physiologic races and vegetative compatibility groups of Fusarium oxysporum f. sp. melonis in Israel. Phytopathology 84:153-157.

39. Kawabe, M., Katsube, K., Yoshida, T., Arie, T., and Tsuchiya, K. 2007 Genetic diversity of Fusarium oxysporum f. sp. spinaciae in Japan based on phylogenetic analyses of rDNA-IGS and MAT1 sequences. J. Gen. Plant Pathol. 73:353-359.

40. Kelly, A. G., Bainbridge, B. W., Heale, J. B., Perez-Artes, E., and JimenezDiaz, R. M. 1998. In planta-polymerase chain reaction detection of the wiltinducing pathotype of Fusarium oxysporum f. sp. ciceris in chickpea (Cicer arietinum L.). Physiol. Mol. Plant Pathol. 52:397-409.

41. Kerr, A. 1963. The root rot Fusarium wilt complex of pea. Aust. J. Biol. Sci. 16:55-69.

42. Kistler, H. C. 1997. Genetic diversity in the plant-pathogenic fungus Fusarium oxysporum. Phytopathology 87:474-479.

43. Komada, H. 1975. Development of a selective medium for quantitative isolation of Fusarium oxysporum from natural soil. Rev. Plant Prot. Res. 8:114-125.

44. Leslie, J. F., and Summerell, B. A. 2006. The Fusarium Laboratory Manual Blackwell Publishing, Ames, IA

45. Lievens, B., Brouer, M., Vanachter, A. C. R. C., Lévesque, C. A., Cammue, B. P. A., and Thomma, B. P. H. J. 2003. Design and development of a DNA 
array for rapid detection and identification of multiple tomato vascular wilt pathogens. FEMS Microbiol. Lett. 223:113-122.

46. Lin, Y.-H., Chang, J.-Y., Liu, E.-T., Chao, C.-P., Huang J.-W., and Chang, P.-F. L. 2009. Development of a molecular marker for specific detection of Fusarium oxysporum f. sp. cubense race 4. Eur. J. Plant Pathol. 123:353365.

47. Ma, L.-J., van der Does, H. C., Borkovich, K. A., Coleman, J. J., Daboussi, M.-J., Di Pietro, A., and 57 others. 2010. Comparative genomics reveals mobile pathogenicity chromosomes in Fusarium. Nature 464:367-373.

48. Mbofung, G. Y., Hong, S. G., and Pryor, B. M. 2007. Phylogeny of Fusarium oxysporum f. sp. lactucae inferred from mitochondrial small subunit, elongation factor $1-\alpha$, and nuclear ribosomal intergenic spacer sequence data. Phytopathology 97:87-98.

49. Metzger, J. D., and Zeevaart, J. A. D. 1985. Spinacia oleracea. Pages 384392 in: CRC Handbook of Flowering, Volume IV. A. H. Halevy, ed. CRC Press, Boca Raton, FL.

50. Nelson, P. E., Toussoun, T. A., and Marasas, W. F. O. 1983. Fusarium Species: an Illustrated Manual for Identification. The Pennsylvania State University Press, Harrisburg.

51. Okubara, P. A., Li, C., Schroeder, K. L., Schumacher, R. T., and Lawrence, N. P. 2007. Improved extraction of Rhizoctonia and Pythium DNA from wheat roots and soil samples using pressure cycling technology. Can. J. Plant Pathol. 29:304-310.

52. Okubara, P. A., Schroeder, K. L., and Paulitz, T. C. 2008. Identification and quantification of Rhizoctonia solani and $R$. oryzae using real-time PCR. Phytopathology 98:837-847.

53. Plyler, T. R., Simone, G. W., Fernandez, D., and Kistler, H. C. 1999. Rapid detection of the Fusarium oxysporum lineage containing the Canary Island date palm wilt pathogen. Phytopathology 89:407-413.

54. Reyes, A. A. 1979. Populations of the spinach wilt pathogen, Fusarium oxy- sporum f. sp. spinaciae, in the root tissues, rhizosphere, and soil in the field. Can. J. Microbiol. 25:227-229.

55. Skovgaard, K., Nirenberg, H. I., O’Donnell, K., and Rosendahl, S. 2001. Evolution of Fusarium oxysporum f. sp. vasinfectum races inferred from multigene genealogies. Phytopathology 91:1231-1237.

56. Vandemark, G. J., and Barker, B. M. 2003. Quantifying Phytophthora medicaginis in susceptible and resistant alfalfa with real-time fluorescent PCR assay. J. Phytopathol. 151:577-583.

57. van der Does, H. C., Lievens, B., Claes, L., Houterman, P. M., Cornelissen, B. J. C., and Rep, M. 2008. The presence of a virulence locus discriminates Fusarium oxysporum isolates causing tomato wilt from other isolates. Environ. Microbiol.10:1475-85.

58. Welsh, J., and McClelland, M. 1990. Fingerprinting genomes using PCR with arbitrary primers. Nucleic Acids Res. 18:7213-7218

59. White, T. J., Bruns, T., Lee, S., and Taylor, J. 1990. Amplification and direct sequencing of fungal ribosomal RNA genes for phylogenetics. Pages 315 322 in: PCR Protocols: A Guide to Methods and Amplifications. Academic Press, Inc., San Diego, CA.

60. Williams, J. G. K., Kubelik, A. R., Livak, K. J., Rafalski, J. A., and Tingey, S. V. 1990. DNA polymorphisms amplified by arbitrary primers are useful as genetic markers. Nucleic Acids Res. 18:6531-6535.

61. Yli-Mattila, T., Mach, R. L., Alekhina, I. A., Bulat, S. A., Koskinen, S. Kullnig-Gradinger, C. M., Kubicek, C. P., and Klemsdal, S. S. 2004. Phylogenetic relationship of Fusarium langsethiae to Fusarium poae and Fusarium sporotrichioides as inferred by IGS, ITS, $\beta$-tubulin sequences and UPPCR hybridization analysis. Int. J. Food Microbiol. 95:267-285.

62. Zambounis, A. G., Paplomatas, E., and Tsaftaris, A. 2007. Intergenic spacer-RFLP analysis and direct quantification of Australian Fusarium oxysporum f. sp. vasinfectum isolates from soil and infected cotton. Plant Dis. 91:1564-1573. 